\title{
NARASI REALISME MAGIS DALAM PUISI "GONG" KARYA NIRWAN DEWANTO
}

\author{
M aharani Intan Andalas \\ Jurusan Bahasa dan Sastra Indonesia \\ Universitas Negeri Semarang \\ Pos-el: intan_andalas@mail.unnes.ac.id
}

\begin{abstract}
A bstrak
Pengaruh kesusastraan global berupa realismemagis ditemukan dalam sastra Indonesia, baik dalam prosa maupun puisi. Salah satu indikasi karya realisme magis adalah dihadirkannya mitos dalam konteks masa kini. Masalah yang dibahas dalam penelitian ini adalah bagaimana yang magis dan yang nyata dinarasikan berdasarkan elemen-elemen yang menjadi karakteristik realisme magis dalam puisi "Gong" serta hubungan antarelemen dan kadar realismemagis di dalamnya. Penelitian ini menggunakan teori naratif realismemagisWendy B. Faris. Metodepenelitian didasarkan pada teori berupa penentuan data dan pengumpulan data yang meliputi klasifikasi data menjadi dua kategori utama, yaitu data magis dan data riil. Dalam hasil dan pembahasan, dibuktikan bahwa puisi "Gong" mengandung narasi realismemagisatas mitosCal on A rang melalui limakarakteristik realisme magis yang terdapat di dalamnya. Selain itu, terdapat hubungan relasional di antara elemen yang menjadi karakteristik tersebut. Kadar realismemagis dilihat dari tokoh dan peristiwa dapat dikatakan cukup kuat. Puisi ini menggarisbawahi isu perempuan dan akhir patriaki. Isu tersebut berkait dengan konteks posmodernisme. Penggunaan mitos dalam puisi memperlihatkan cara pandang posmodernisme yang tidak terlepas dari Jakarta sebagai konteks sosial penyair.
\end{abstract}

Kata kunci : mitos, narasi, real isme, magis, karakteristik

\begin{abstract}
The impact of global literature of magical realism is found in Indonesia literature in both prose and poetry. O neindication of the work of magical realism is the representation of myth in thecontemporary context. The problem discussed in this research arethenarration of themagic and the real in $\mathrm{G}$ ong poem and theconnection between elements, al so the level of magical realism in it. This research used narrativetheory of magical real ism by $W$ endy $B F$ aris. This research method was based on magical real ism theory in theform of data determination and data collection which included the classification into two categories namely magical data and real data. In result and discussion proved that Gong poem contained a narrative of magical realism upon Calon A rang myth through five characteristic of magical realism in it beside the relation among the elements. M agical realism level seen from character and events was strong enough. This poem underlines theissues of women and the end of patriarchy. The issues are related with postmodernism context. The myths in poem shows postmodernism point of view that can't be separatefrom Jakarta as social context.
\end{abstract}

Keyw ords: myth, narrative, magical, realism, characteristic

\section{PEN DAHULUAN}

Pada '90-an, posmodernisme merupakan aliran yang banyak dibicarakan dan dianggap berpengaruh pada wacana budaya, seni, dan sastra di Indonesia. Seiring dengan semangat posmodernisme, muncul aliran kesusastraan yang disebut realisme magis. Realisme magis dipandang sebagai respon atas modernisme yang mengungkapkan cara pandang baru terhadap realitas. Aliran ini pada mulanya ditujukan pada ledakan sastra Amerika Latin yang muncul pada akhir 1960-an, secara khusus pada novel Seratus Tahun Kesunyian karya Gabriel Garcia Marquez yang terbit pada 1967 
(Dewanto, 1999: xiii"xviii). Novel tersebut berhasil mengantarkan pengarangnya meraih hadiah nobel pada 1982 hingga dikukuhkan sebagai salah satu kanon karya realisme magis sekaligus membuat aliran ini diakui sebagai perwujudan estetika baru dalam kesusastraan dunia. Pada 1980-an dan awal 1990-an, realisme magis mulai mendunia yang pengaruhnya dapat dilihat pada karya sastra di luar A merika Latin (Hart dan Wen-Chin Ouyang, 2005:11). Tidak dapat dimungkiri bahwa sejumlah karya pengarang Amerika Latin pada 1980-an telah dikenal oleh pengarang Indonesia. Salah seorang sastrawan yang mengalihbahasakan cerpen karya Gabriel Garcia Marquez adalah Nirwan Dewanto. Cerpen tersebut berjudul "Lelaki Tua Bersayap" dari Leaf Strom and 0 ther Stories terjemahan Gregory Rabassa yang dimuat dalam Suara Pembaharuan pada 16 Oktober 1988.

Dimunculkannya kembali mitos, dongeng, dan legenda sebagai hal yang magis dan tradisional ke dalam realitas atau dunia modern dapat dipandang sebagai indikasi karya realisme magis. Pengaruh realisme magis dapat dilihat dalam puisi Indonesia sebagaimana puisi "Gending Pulebahasan" karya Badruddin Emce yang dibuktikan mengandung penarasian atas yang magis dan yang nyata dengan menghadirkan kembali mitos yang bersumber pada teks tradisional (Iswandari, 2014). Selain Badruddin Emce, penyair yang memiliki kecenderungan menghadirkan kembali mitos adalah Nirwan Dewanto dalam puisi yang berjudul "Gong". Puisi ini mengangkat narasi tentang mitos melalui penyebutan tokoh mitologis di dalamnya, yaitu Ratna Manggali. Pe nyebutan tokoh mitologis tersebut menyebabkan puisi ini terhubung dengan kisah Calon A rang.

Puisi “Gong" termuat dalam himpunan puisi Jantung Lebah Ratu (selanjutnya tertulis JLR). Buku puisi ini diterbitkan pada 2008 oleh Gramedia Pustaka Utama dan dalam tahun yang sama Penghargaan Sastra Khatulistiwa berhasil diraihnya. Himpunan puisi tersebut terdiri atas halaman judul, daftar isi yang mengelompokkan puisi ke dalam tiga bagian dengan sebutan kantung, dan catatan yang berisi penjelasan atas beberapa puisi. Di dalam himpunan puisi JLR, terdapat empat puluh enam buah puisi. "Gong" merupakan puisi keenam yang berada dalam Kantung Kesatu. Pada cacatan dua himpunan puisi tersebut dijelaskan bahwa harian Kompas juga telah memuat “Gong” pada 11 Februari 2007.

Dalam sastra Indonesia modern, kisah Calon Arang dituliskan atau diceritakan kembali oleh beberapa pengarang dalam bentuk prosa, yaitu Cerita Calon A rang oleh Pramoedya Ananta Toer pada 1954 yang diterbitkan kembali pada tahun 2003, Calon A rang dari Jirah oleh Mu'jizah pada 1995, Calon A rang: Kisah Perempuan Korban Patriaki oleh Toeti Heraty pada 2000 berupa prosa lirik, dan Janda dari Jirah oleh Cok Sawitri pada 2007. Kisah Calon Arang juga diciptakan kembali dalam bahasa Inggris oleh Goenawan Mohamad dengan judul The King's Witch dalam bentuk libretto (kata-kata yang dinyanyikan atau diucapkan dalam pertunjukan opera atau musik). Dari berbagai bentuk transformasi teks Cal on Arang, setiap penulis memiliki sudut pandang tertentu dalam menuturkannya dan tidak dapat sangkal bahwa perempuanlah yang menjadi pembicaraan di dalam teks tersebut.

Berbeda dengan sastrawan Indonesia sebelumnya, Nirwan Dewanto memilih bentuk puisi untuk menghadirkan kembali kisah Calon Arang. Dalam "Gong" terdapat rangkaian peristiwa berupa tindakan-tindakan yang berkaitan dengan keberadaan-keberadaan yang menggambarkan kenyataan dan hal-hal yang magis dan mitologis. Hal-hal itu dapat dikaitkan dengan konteks di luar puisi, seperti isu mengenai perempuan dan patriaki yang dipandang secara berbeda melalui kisah tersebut. Sejauh pengetahuan peneliti, analisis terhadap "Gong" dengan menggunakan konsep teori realisme magis belum dilakukan. Meskipun 
teori tersebut dibangun dari kajian-kajian terhadap fiksi naratif, dengan meletakkan puisi "Gong" sebagai puisi naratif, pemanfaatan teori ini menjadi niscaya untuk dilakukan.

Dalam pembicaraan mengenai jenis-jenis sastra, Luxemburg, dkk. (1989:111) menyatakan bahwa sajak (puisi) naratif adalah sajak yang menyajikan serangkaian peristiwa. Situasi bahasa berupa monolog, tetapi isi berupa cerita. Hal ini menyebabkan sajak naratif memiliki bentuk campuran sehingga dapat didekati dari sudut naratif, puitik, atau keduanya-duanya bersama-sama. A danya aspek naratif dalam puisi juga diungkap oleh Brian McHale pada artikel "Beginning to Think about $\mathrm{N}$ arrative in P oetry" (N arrative. 2009). Secara tipografi, puisi ini berbentuk lurus rata kiri dan memiliki dua belas bait. Bait-bait tersebut disusun oleh satu baris atau beberapa baris kalimat dengan enjambemen yang memperlihatkan kesatuan sintaksis. Hubungan antarbait ditandai dengan adanya jarak atau spasi sehingga bait-bait tersebut hampir menyerupai paragraf. Setiap bait mengindikasikan peristiwa-peristiwa yang disusun dalam kesatuan ide naratif disertai penggunaan tanda baca berupa titik, koma, petik dua, titik dua, tanda tanya, tanda seru, dan tanda kurung. Secara keseluruhan, puisi ini terdiri atas tiga puluh delapan kalimat. Dengan mempertimbangkan hal-hal tersebut, teori realisme magis dimanfaatkan oleh penel iti untuk menganalisis puisi "Gong".

\section{TEORI DAN METODE}

Realisme magis sebagai istilah dicetuskan oleh kritikus seni Jerman bernama Franz Roh pada 1920-an, yang muncul dalam kaitannya dengan penilaian atas lukisan di Republik Weimar, yang berusaha menangkap misteri kehidupan di balik kenyataan yang ada di permukaan (Bowers, 2004:2). Lebih Ianjut, Bowers (2004:3) mengatakan bahwa hal yang membedakan realisme magis dengan sastra realisme ialah penyatuan dua aspek yang beroposisi sebagai oksimoron-paradox yang menggunakan penjajaran kata yang berlawanan-(magis dan nyata) secara bersamaan untuk membentuk perspektif baru.

Selain pendapat di atas, realisme magis didefinisikan pula oleh Wendy B. Faris. Real isme magis menggabungkan realisme dan yang fantastik sehingga yang mengagumkan tampak tumbuh secara organik di dal am yang biasa dan mengaburkan perbedaan di antara keduanya. Kombinasi atas narasi yang riil dan fantastik, bersama dengan penyertaan tradisi budaya yang berbeda, berarti bahwa realisme magis merefleksikan mode naratif dan lingkungan budaya keduanya, yakni alam hibrid pada masyarakat poskolonial (Faris, 2004:1). Dalam penelitian ini, pendapat Faris tersebut, sebagaimana yang tercantum dalam bukunya 0 rdinary Enchanments: M agical Realism and the Remystification of $\mathrm{N}$ arrative, digunakan sebagai landasan teoretis untuk menjelaskan realisme magis yang terdapat dalam puisi "Gong".

Menurut Wendy B. Faris (2004), terdapat lima karakteristik dari karya realisme magis, yaitu elemen taktereduksi (the irreducible element), dunia fenomenal (the phenomenal world), keraguan takberakhir (unsettling doubts), penggabungan alam (merging realms), dan gangguan atas waktu, ruang, dan identitas (disruptions of time, space and identity).

Menurut Faris (2004:7), elemen yang taktereduksi adalah hal-hal yang tidak dapat dijelaskan menurut hukum al am sebagaimana diformulasikan dalam wacana empiris Barat, yakni berdasarkan logika, pengetahuan umum, atau kepercayaan yang ada. Oleh karena itu, pembaca kesulitan menyusun bukti untuk menjawab pertanyaan-pertanyaan tentang status peristiwa-peristiwa dan tokoh-tokoh dalam teks realisme magis. Di samping itu, Faris (2004:9"10) mengatakan bahwa peristiwa dan tokoh magis sebagai elemen yang taktereduksi kerap menggarisbawahi isu-isu sentral dalam teks. Isu tersebut dapat dihubungkan dengan konteks yang terjadi di luar karya sastra. Karakteristik kedua karya realisme 
magis adalah karya tersebut menggambarkan secara rinci sebuah keberadaan kuat dari dunia fenomenal (the phenomenal world). Dunia tersebut merupakan bentuk realisme dalam realisme magis yang membedakannya dari karya sastra fantasi dan alegori. Karakteristik ketiga dalam karya realisme magis berupa keraguan takberakhir (unsettling doubts). Faris (2004:17) menyatakan bahwa karakter ini muncul sebelum pengategorian suatu elemen sebagai elemen taktereduksi. Pembaca ragu-ragu antara dua pemahaman yang bertentangan atas peristiwa-peristiwa sehingga mengalami keraguan yang tidak berkesudahan. Keraguan muncul karena yang magis (tradisional) dinarasikan melalui perspektif (empirik) dan model realisme. Lebih Ianjut, Faris (2004:19) menyebutkan bahwa keraguan disebabkan oleh tiga hal, yaitu pertama, keraguan atas peristiwa-peristiwa yang dinarasikan dalam teks; kedua, keraguan yang ditimbulkan oleh fenomena atau objek tertentu; ketiga, keraguan atas mana yang fakta dan fiksi.

Karakter keempat realisme magis adalah penggabungan dua alam atau dunia-dunia. Melalui penarasian yang membaurkan dua alam, realisme magis membuka ruang antara (a space of the in-between) dan ruang ketidakpastian (a space of uncertainty), yaitu ruangruang yang mendekatkan atau mempertemukan alam yang berbeda. Menurut Faris (2004: 21), dipandang dari cakupan sejarah kultural, realisme magis kerap menggabungkan dunia tradisional, kuno, dan asli dengan dunia modern. Secara ontologis dalam teks, penggabungan alam mengintegrasikan yang magis dengan yang material dan secara awam, menyatukan realisme dengan yang fantastik. Karakteristik terakhir karya real isme magis adal ah gangguan terhadap waktu, ruang, dan identitas (disruptions of time, space, and identity). Salah satu hal yang telah dicapai realisme adalah "kemunculan ruang dan waktu yang baru" karena homogenitas spasial realisme telah menghapuskan bentuk-bentuk lama dari ruang sakral. Begitu juga pengukuran waktu yang baru dan rutinitas yang dapat diukur telah mengganti “bentuk-bentuk lama dari ritual, yang disakralkan, atau waktu siklus". Dalam karya realisme magis, bentuk-bentuk hitungan temporal yang dibuang oleh paham modern juga bentukbentuk spasial yang diasingkan oleh konsep ruang modern dihadirkan kembali. Lebih Ianjut, realisme magis juga mereorientasi kesadaran pembaca tidak hanya mengenai ruang dan waktu, tetapi juga identitas. Dalam penggambaran tentang identitas individu, sifat multivokal naratif dan hibriditas kultural menggapai ke dalam identitas karakter-karakter (Faris, 2004:25). Sifat-sifat tersebut dapat mewujud ke dalam karakter fisik tokoh-tokohnya. Identitas, yang dipahami dalam dunia modern sebagai suatu entitas tunggal yang berada dalam diri seseorang dan membedakan dirinya dengan entitas lainnya, mengalami gangguan sehingga tampak bentuk yang berlipat-lipat dalam diri seorang individu (multiply identity).

Kelima karakteristik di atas secara keseluruhan mendefinisikan karya realismemagis dan memberikan gambaran mengenai struktur naratif dari karya realisme magis sebagai sebuah teknik naratif yang mempertemukan unsur-unsur magis dan realisme di dalamnya. Melalui kelima karakteristik tersebut kemudian dapat terlihat bagaimana hubungan relasional di antara keduanya, seperti ketumpangtindihan antara peristiwa yang magis dengan yang riil sehingga menimbulkan keraguan, pertemuan yang magis dan riil dalam alam antara, dan gangguan sebagai akibat interaksi unsur-unsur magis terhadap konsep-konsep realisme. Dari hubungan relasional tersebut, dapat diperlihatkan susunan tingkat antarunsur magis dan riil dalam karya realisme magis. Berbeda dengan kecenderungan realisme yang melihat hubungan antara yang magis dan yang riil secara hierarkis, karya real isme magis mel etakkan posisi dan hubungan antara keduanya untuk disejajarkan. Dengan demikian, muncul alternatif baru dalam memandang real itas yang 
menjadikan realisme magis memiliki kecenderungan posmodern. Melalui strategi naratif di dalamnya, yang magis, mitos, dan yang nyata digunakan pengarang untuk mengungkapkan isu-isu penting yang terkait dengan konteks tertentu.

Metode yang digunakan dalam penelitian ini didasarkan pada teori di atas berupa penentuan data dan pengumpulan data yang meliputi klasifikasi data menjadi dua kategori utama, yaitu data magis dan data riil. Data primer yang dijadikan acuan dalam penelitian ini ialah satuan-satuan tekstual yang berasal dari puisi "Gong" karya Nirwan Dewanto. Data-data tekstual tersebut dapat berupa satuan-satuan kata, tanda baca, frase, kal imat, baris kalimat, bait, ataupun rangkaian peristiwa yang terdapat di dalam puisi tersebut. Data sekunder yang digunakan dalam penelitian ini ialah data yang berasal dari teks-teks yang berada di luar puisi "Gong" yang dianggap terkait. Secara khusus, teks-teksyang dimaksudkan adalah teks-teks tradisional dan modern yang mengisahkan Calon A rang, dan sumbersumber penelitian ilmiah lain, jurnal, buku serta artikel.

Dalam mengumpulkan data primer, satuan-satuan data yang disebutkan sebelumnya dikumpulkan dan dikelompokkan ke dalam dua kategori utama, yaitu kategori data magis dan kategori data riil, yang kemudian dinamai menurut teori Faris sebagai elemen taktereduksi untuk kategori pertama dan dunia fenomenal untuk kategori kedua. Kemudian data-data yang berada dalam dua kategori tersebut dirangkai kembali hubungannya untuk melihat pola relasinya. Bentuk pertama yaitu elemen magis yang bertemu dengan elemen riil yang menimbulkan keraguan yang disebut sebagai the unsettling doubts (keraguan takberakhir). Bentuk kedua adalah saling bercampurnya antara elemen magis dan elemen riil sehingga berada dalam ruang antara (in-between) yang kemudian dinamai merging realms (penggabungan alam). Kategori selanjutnya di- bangun berdasarkan gangguan terhadap nilainilai modern tentang waktu, ruang, dan identitas yang kemudian dinamai disruptions of time, space, and identity.

\section{HASIL DAN PEMBAHASAN}

\section{Karakteristik dan Kadar Realisme Magis dalam Puisi "Gong"}

Keberadaan elemen taktereduksi dalam puisi"Gong" dapat diketahui pertama-tama dengan mencari yang magis, yaitu berupa tokoh, dan peristiwa-peristiwa magis di dalamnya. Yang magis tersebut dikategorikan sebagai sesuatu yang irreducible atau reducible. Beberapa tokoh magis dan sekaligus mitologis di antaranya, Ratna Manggali, sang panakawan, ki lurah Baradah, balatentara Kadiri, janda dari Girah, Durga, dan Siwa. Peristiwa magis yang ada dalam puisi ini, yaitu adinda yang menari dalam lingkaran, penghitaman alis, penebaran beras kuning, daun sirih, dan pecahan pedang di kaki ranjang agar tokoh aku dapat segera menari setelah bangun pagi.

Dalam posisi sebagai adinda yang menari dalam lingkaran, Ratna Manggali digambarkan dengan mendetail dan konkret, tetapi sekaligus magis. Baiklah, bahkan lingkaran seluas padang ara-ara pun tak cukup bagimu. Penggambaran Ratna Manggali yang dominan sebagai penari menunjukkan adanya pergeseran atas peran dan posisinya terhadap kisah Calon A rang yang tradisional. Ratna Manggali pada kisah Calon Arang tradisional diposisikan sebagai istri yang membantu suaminya, Mpu Bahula, mengambil buku sihir milik ibunya (lih. Mu'jizah, 1995; Heraty; 200; Pramoedya, 2003). Peristiwa magis ini dengan demikian menggarisbawahi isu sentral melalui tokoh Ratna Manggali. Dalam mitos Calon Arang, Ratna Manggali dimarjinalkan sebagai perempuan yang tidak berdaya, sedangkan puisi ini menjadikannya sebagai tokoh sentral yang memiliki kekuatan. 
Dunia fenomenal dalam puisi ditemukan melalui identifikasi adanya tempat, benda, tokoh, dan peristiwa yang dianggap nyata atau fenomenal. Tempat nyata yang disebutkan di dalamnya, yaitu sayap dan tirai panggung serta Prabalingga, Kadiri, dan Girah. Benda nyata yang disebutkan, yaitu gong. Tokoh nyata yang disebutkan, yaitu para penabuh. Selanjutnya, peristiwa yang dianggap nyata di dalam puisi ini, yaitu hamparan abu yang meluas sampai ke Prabalingga.

Sayap panggung (bait ke-4, kalimat ke-19) dalam puisi ini digambarkan sebagai tempat balatentara Kadiri bersembunyi untuk mengintai Ratna Manggali, sedangkan tirai panggung (bait ke-10, kalimat ke-34) digambarkan melalui tokoh aku sebagai tempat yang akan terkena cahaya pagi sehingga peristiwa yang terjadi antara tokoh aku dan tokoh kau atau Ratna Manggali harus berakhir. Sayap panggung dan tirai panggung dengan demikian digunakan sebagai ruang nyata yang memungkinkan mitos dihadirkan kembali dalam dunia masa kini. Dunia fenomenal lainnya dalam puisi ini, yaitu Prabalingga, Kadiri, dan Girah. Ketiga tempat tersebut dapat dirujuk, baik dalam kenyataan masa lampau maupun masa kini. Secara etimologis, Probolinggo dalam bahasa Sansekerta berasal dari kata praba dan lingga. Praba berarti sinar, sedangkan lingga berarti tanda, badan, wujud, tongkat, tugu, asli, dan sederhana. Dalam puisi, Prabalingga digambarkan sebagai tempat yang terjangkau oleh hamparan abu yang meluas. Hamparan abu yang meluas itu menimbulkan pertanyaan bagi tokoh aku bersamaandengan kedatangan tokoh kau atau Ratna Manggali. Prabalingga dengan demikian terhubung dengan mitos Calon Arang sebagai yang fenomenal. Tokoh narator berada dalam dunia riil dalam memahami sesuatu yang terkait dengan mitos.

Benda nyata yang disebutkan dalam puisi ini adalah gong yang menjadi judul puisi. Gong merupakan logam bulat berpencu (tonjolan di titik pusat tempat seorang pemain atau nayaga memukulnya). Gong yang digantung pada tali pada gayor (palang penahan) bergema sebab badan gong pada lazimnya berongga cekung di bagian belakangnya. Gong dalam pengertian Barat adalah semua alat musik gamelan yang berpencu,seperti ketuk, kenong, bonang (Banoe, 2003: 168"169). Meski gong dalam puisi ini hanya disebut satu kali, gong sebagai yang nyata dideskripsikan melalui tokoh dan peristiwa-peristiwa, baik yang magis maupun yang nyata sehinga gong tidak hanya menjadi objek, tetapi sekaligus juga subjek yang di dalamnya terdapat makna yang lebih luas. Takwin (2009) mengungkapkan bahwa keberadaan gong dalam puisi "Gong" dipertanyakan, sebagai pencerita atau gong menjadi kategori yang memungkin cerita, yang terbuka dan siap dilampaui. Gong menjadi terhubung dengan mitos Calon A rang yang memungkinkan untuk dimaknai secara simbolis. Gong dalam gamelan Bali memiliki makna simbolis, yaitu dianggap sebagai surga (Bandem, 1996: 40).

Tokoh nyata dalam puisi ini adalah para penabuh (bait ke-5). Para penabuh dikenali sebagai yang nyata pertama-tama melalui ketidakhadirannya di dalam cerita mitos Calon Arang tradisional. Kedua, para penabuh berkait dengan gong sebagai objek, melalui deskripsi dalam bait puisi, yang menyertakan rincian magis dari tokoh magis dan peristiwaperistiwa yang dialaminya. Oleh karena itu, para penabuh dapat dikaikan dengan gong dan gamelan yang memiliki fungsi tertentu dalam kebudayaan Jawa dan Bali. Geertz (1980) menyebutkan bahwa gong merupakan simbol bagi kekuasaan Raja dalam tradisi Bali. Ketiga, penabuh sebagai tokoh kami menjadi fenomenal karena direpresentasikan melalui penarasian yang realistik dari narator berkait dengan tokoh aku, Ratna Manggali, Siwa, dan peristiwa datangnya pagi yang mengakhiri pertunjukkan (tirai panggung) di antara mereka.

Karakteristik karya realisme magis selanjutnya berupa keraguan takberakhir. Dalam puisi 
ini, keraguan pertama ditimbulkan oleh tokoh narator. Tokoh ini pertama kali muncul di awal bait puisi dengan penyebutan sebagai kami (kalimat ke-1 dan ke-4). Tengah kami cerna hamparan abu yang meluas hingga ke Prabalingga. Selain menyebut dirinya sebagai tokoh kami, dalam bait ini narator juga berperan sebagai aku. N arator, sebagai aku yang menjadi bagian dari tokoh kami, tidak dapat sepenuhnya dikatakan berada di dunia mitos tempat Ratna Manggali berada meskipun melalui aku suara tokoh mitos tersebut terdengar. M enyuapkan sebilah anak kunci ke mulutku kau berkata, "A ku pandai membuka semua pintu. Jangan lagi lari dariku".

Peristiwayang menimbukan keraguan bagi pembaca dalam puisi ini adalah penguburan sang panakawan (bait ke-1). Panakawan merupakan tokoh magis yang keberadaannya tidak nyata sehingga penguburan terhadap tokoh ini menjadi mengganggu logika empirik. Peristiwa tersebut melibatkan tokoh narator dalam dunia riil pada saat memahami hamparan abu yang meluas hingga ke Prabalingga sehingga pembaca merasa ragu mengenai status sang panakawan. A pakah tokoh panakawan nyata atau hanya sekedar tokoh mitos dan magis? Panakawan dalam mitos adalah rakyat jelata atau abdi setia para kesatria dan raja yang juga berperan sebagai penerjemah pada bahasa kesatria atau raja. Zoetmulder (1994: 368) menyebutkan bahwa tokoh panakawan merupakan tokoh badut yang menemani tokoh utama yang selalu muncul dal am pertunjukkan wayang atau pertunjukkan yang serupa di Jawa dan Bali.

A pabila narator berada dalam dunia riil, pembaca tergoda untuk menjadikan peristiwa penguburan panakawan sebagai yang riil pula, yaitu sebagai metafora bagi tidak adanya lagi pemberi interpretasi atau penerjemah bagi mitos dalam kenyataan masa kini atau mitos yang tidak lagi dimengerti dalam dunia riil. Namun, teks menyebutkan bahwa peristiwaitu melibatkan tokoh magis yang dinyatakan juga pada bait ke-10, dan kuburan panakawan itu, tepat di bawah julai tandan pisang raja, akan segera terlihat olehmu, sehingga teks melarang untuk mengkooptasi peristiwa tersebut sebagai riil. Jika peristiwa tersebut magis, maka keberadaan panakawan sebagai tokoh magis dan kematiannya juga hanya dapat terjadi di dunia mitos, tetapi hal ini juga menimbulkan keraguan bagi pembaca karena tokoh narator tidak dapat sepenuhnya dikatakan sebagai tokoh yang hidup dalam dunia mitos.

Penggabungan alam nyata dan magis dalam puisi "Gong" ditemukan melalui tokoh aku, para penabuh, dan tempat yang mendekatkan dua alam tersebut, yaitu panggung dan Sumeru. Sebagai tokoh yang statusnya meragukan, aku berada dalam dua alam sehingga membuatnya berada dalam posisi tidak pasti atau posisi di antara. Aku berhubungan dengan objek-objek riil di dunia fenomenal, tetapi aku juga berkaitan dengan tokoh magis dan menyuarakannya. Dalam bait ke-4, yang magis, mitologis hadir dan didekatkan pada sebuah tempat yang berada dalam alam riil, yaitu sayap panggung. Bahkan balatentara Kadiri yang mengintai dari kedua sayap panggung gentar ol eh kilaumu, ol eh ketelanjanganmu. Sayap panggung merupakan bagian kanan dan kiri panggung yang tersembunyi dari penonton, yang biasanya digunakan para aktor menunggu giliran sesaat sebelum tampil. Sampai di sini, alam magis juga tradisonal berupa tokoh-tokoh dalam dunia kerajaan, yaitu balatentara Kadiri, sebagaimana yang terdapat juga dalam teks Calonarang tradisional, dan tokoh mitologis Ratna Manggali terwujudkan dalam alam nyata, dalam dunia di atas panggung bukan di masa lampau. Dengan kata lain, alam yang jauh di masa lampau, yang tradisional dihadirkan pada masa kini, dapat disaksikan dalam panggung. Panggung dengan demikian menjadi yang riil sekaligus tempat bagi hadirnya yang magis.

Selanjutnya, pada bait ke-5, penggabungan dua alam, yang magis dan nyata diperlihat- 
kan melalui tokoh para penabuh. Setiap kali para penabuh menjalang hendak menggiringmu ke tepi jurang, kugaungkan diriku lirih panjangpanjang. Para penabuh muncul dalam bait ini sebagai tokoh yang tidak dapat ditemukan keberadaannya dalam teks Calon Arang tradisional. Namun, disebutkannya sayap panggung pada bait sebelumnya menyebabkan keberadaan para penabuh menjadi dimungkinkan. Penabuh dapat hadir di panggung di alam riil. Para penabuh merupakan tokoh dunia riil, di atas panggung, yang memungkinkan hadirnya alam magis untuk bergabung dalam alam nyata melalui musik atau bunyi dari alat musik atau benda yang ditabuhnya.

Selain panggung, penggabungan alam magis dan nyata terjadi di Sumeru. Penyebutan Sumeru dituturkan melalui tokoh aku dalam bait ke-8. M aka kugiring kau ke puncak (Sumeru, itulah mungkin namanya). Dalam bait sebelumnya, para penabuh bermaksud menggiring tokoh kau ke tepi jurang, tetapi tokoh aku memintanya untuk kembali ketengah. Dalam bait ini, tokoh aku menggi ring tokoh kau kepuncak. Puncak itu dikatakan mungkin bernama Sumeru. Jika dikaitkan dengan Sumeru, maka puncak itu merujuk pada gunung mitologis yang ada dalam kosmologi Hindu dan Budha. Sumeru dalam bahasa Sansekerta berarti Meru yang agung. Gunung Sumeru atau Meru merupakan gunung suci yang dianggap sebagai pusat alam semesta baik secara fisik maupun metafisik. Selain sebagai gunung mitologis, di Indonesia Sumeru merupakan gunung yang nyata keberadaannya dengan sebutan yang sedikit berbeda, yaitu Semeru. Secara geografis, Gunung Semeru terletak di wilayah kabupaten Lumajang dan Malang di Provinsi Jawa Timur. Dalam agama Hindu, terdapat kepercayaan terhadap Gunung Meru, yaitu sebagai tempat tinggal dewa-dewa dan sebagai sarana penghubung antara manusia (bumi) dengan khayangan. Hingga saat ini Gunung Semeru yang merupakan gunung tertinggi di Pulau Jawa ini dipercaya oleh masyarakat Bali sebagai bapak dari Gunung Agung di Bali dan tempat tinggal para dewa. Baik sebagai yang mitologis maupun nyata, Sumeru dipercaya sebagai tempat bertemunya alam atau dunia-dunia yang berbeda. Dalam puisi ini, melalui tokoh aku, Ratna Manggali, yang sebelumnya hadir bersama dengan para penabuh di atas di panggung, dibawa (digiring) kepuncak, di tempat tertinggi yang mempertemukan alam nyata dan alam magis.

Dalam puisi "gong", konsep modern atas waktu, ruang, dan identitas juga mengalami gangguan. Gangguan waktu terjadi saat hadirnya yang magis secara misterius ke dal am waktu riil sehingga waktu di dalam alam magis tersebut dan peristiwa-peristiwanya terikat pada waktu riil. Gangguan ruang terjadi pada saat peristiwa tarian dari tokoh magis, Ratna Manggali, sedangkan gangguan identitas terjadi pada tokoh-tokoh, baik yang magis mupun yang nyata, disebabkan oleh saling terhubungnya identitas antartokoh dan transformasi identitas tokohnya.

Puisi "Gong" memiliki sepuluh tokoh dengan kecenderungan yang berbeda. Empat tokoh cenderung sebagai yang magis, yaitu ki Iurah Baradah, balatentara Kadiri, Durga yang muncul tidak secara langsung melalui topeng yang dipasang ke wajah Adinda, dan Siwa, sedangkan satu tokoh cenderung sebagai yang nyata, yakni para penabuh. Lima tokoh lainnya, yaitu adinda (Ratna Manggali), sang perias (janda dari Girah, Ibu), delapan penari bertubuh perunggu, sang panakawan, dan narator adalah tokoh-tokoh yang berada pada posisi di tengah dan meragukan sebagai yang nyata ataupun yang magis. Dengan demikian, kadar magis dilihat dari seluruh tokoh dalam puisi “Gong" lebih kuat daripada kadar realis, tetapi dalam posisi tengah terdapat sejumlah tokoh yang berada di antara yang magis dan nyata sehingga berdasarkan penggambaran tersebut kadar narasi real isme magis atas tokoh dapat dikatakan cukup kuat. 
Puisi “Gong" memiliki satu peristiwa yang memiliki kecenderungan magis, yakni ritual yang dilakukan penari, dalam hal ini oleh Ratna M anggali atau adinda, sebelum memulai tarian (reducible) dan dua peristiwa yang cenderung pada realis, yakni hamparan abu yang meluas hingga Prabalingga dan para penabuh yang menjalang. Selain itu, puisi ini memperlihatkan empat peristiwa yang berada pada posisi antara, yakni penguburan sang panakawan (unsettling doubts), tarian adinda dalam lingkaran (irreducible dan disruption), balatentara Kadiri yang mengintai dari kedua sayap panggung (phenomenal dan merging), dan transformasi tokoh aku sebagai yang nyata dan magis (merging dan disruption). Dari kecenderungan peristiwa-peristiwa di atas, kadar peristiwa magis dan riil tidak begitu kuat. Akan tetapi, sejumlah peristiwa tampak berada di tengah sehingga puisi ini dilihat melalui strategi penarasian peristiwa-peristiwanya cenderung berada di antara realisme dan magis. Dengan demikian, puisi "Gong" dilihat berdasar kecenderungan tokoh-tokoh, benda, dan peristiwa-peristiwanya dapat dikatakan sebagai karya yang berada di antara realisme dan magis dengan kadar yang kuat.

\section{Perempuan dan Akhir Patriaki}

Peristiwa taktereduksi berupa tarian adinda, Ratna Manggali, dalam lingkaran menggarisbawahi isu mengenai perempuan. Ratna Manggali dalam posisi sebagai adinda yang menari dalam lingkaran, digambarkan dengan mendetail dan konkret, tetapi sekaligus magis. Peristiwa tersebut menunjukkan adanya perbedaan peran Ratna Manggali jika dibandingkan dengan kisah mitos. Jika mitos memosisikan Ratna Manggali sebagai korban sekal igus penyebab dari kematian Calon A rang, puisi ini memosisikan sebaliknya. Ratna Manggali menjadi tokoh perempuan perawan dengan kekuatan magis dalam tariannya. Selain itu, mitos dalam puisi berkait dengan benda dan tokoh nyata dalam dunia feno- menal, yakni gong, para penabuh, sayap, dan tirai panggung. $\mathrm{H}$ al tersebut menunjukkan bahwa Ratna Manggali sebagai yang magis irreducible dalam puisi "Gong", terhubung pula dengan seni pertunjukan, seperti dramatari Calon A rang dan drama Gong. Kedua pertunjukan ini dapat menjadi sisi realisme dalam puisi “Gong" yang memperlihatkan eksistensi mitos dalam dunia nyata.

Meskipun mengangkat kisah mitos yang sama, pertunjukan dramatari Calon A rang dan drama Gong memiliki sejarah kemunculan yang berbeda di Bali. Namun, keduanya selalu melibatkan para penabuh dan gamelan sebagai iringan pertunjukan. Soedarsono dan Narawati (2011: 146-148) menyatakan bahwa dramatari Calon Arang merupakan pertunjukan tradisional yang telah cukup tua usianya karena tema yang ditampilkan berkaitan dengan konsep rwa bhineda. Masyarakat Bali yang beragama Hindu Bali (Hindu Darma) memegang teguh konsep rwa bhineda. Artinya, dalam hidup ini selalu terdapat dua sifat dan kekuatan yang berbeda, tetapi salah satunya tidak oleh ditiadakan (Soedarsono dan Narawati, 2011: 147). Banyak desa di Bali yang memiliki grup dramatari Calon Arang yang fungsinya untuk menghadirkan keseimbangan dunia yang disel enggarakan pada upara odalan, yakni upacara untuk memperingati berdirinya sebuah pura dengan menghadirkan dewa agar bisa memberikan berkah kepada masyarakat desa yang bersangkutan. Dalam perkembangannya, dramatari ini dikemas pula sebagai seni pertunjukan wisata.

Berbeda dengan dramatari Calon Arang, drama Gong muncul pada 1966 di desa A bianse, yang terletak kurang lebih dua puluh kilometer di sebelah Selatan Denpasar, oleh A nak Agung Gde Raka Payadnya sebagai seniman penggagasnya. Drama Gong bertolak dari teater tradisional, yakni dramatari Arja dan Prembon yang dipadu dengan unsur-unsur teater modern. Pemberian nama 'drama Gong' didasarkan pada bentuk ilustrasi musiknya 
yang menggunakan iringan gong kebyar. Spiller (2004: 117"126) menyatakan bahwa gong kebyar merupakan jenis ansambel gamelan Bali pada periode baru (abad ke-20). Drama ini pada dasarnya merupakan seni pertunjukan rakyat yang memadukan gerak, cerita, musik, busana, dan rias yang di dalamnya terdapat percampuran bentuk seni drama tradisional Bali, drama komedi, sendratari, dan drama modern (Yuliadi, 2005:2"6). Pengaruh unsur-unsur teater modern tampak pada tatapentas, tata-suara, tata-busana, dan tata-laku yang cenderung pada realisme. Pilihan Iakon dalam pementasan drama Gong berasal dari lakon-lakon klasik dan modern dengan tema universal, yakni kebenaran senatiasa di atas kebatilan. Lakon-lakon klasik diambil dari dramatari tradisonal, legenda, ataupun cerita rakyat, seperti Panji, Ramayana, Calon Arang, Jayaprana-Layonsari. Selama pementasan berlangsung, iringan orkes gong terus diperdengarkan sebagai ilustrasi yang membantu menciptakan suasana lakon. Dalam drama ini, adegan pertama selalu dimulai dengan menampilkan para panakawan (Soelarso, B dan S. IImi Albiladiyah, 1975:13"24). Hal lain yang menarik adalah penggunaan bahasa campuran, yakni bahasa Bali dan bahasa Indonesia di dalamnya. Drama gong dalam perkembangannya telah menjadi pertunjukan rakyat yang populer di Bali.

Puisi "Gong" tidak menggunakan mitos dengan cara yang sama seperti apa yang ditampilkan dalam seni pertunjukan di dunia riil. A pabila seni pertunjukan yang menampilkan mitos, yang memosisikan Ratna Manggali dan Calon Arang sebagai yang tersubordinasi, dapat dianggap sebagai bentuk patriaki, puisi ini menampilkan hubungan antara tokoh perempuan dan yang lain, dalam kaitannya dengan kekuatan ataupun kekuasaan, melalui metafora juga simbol yang menunjukkan akhir dari patriaki. Hal ini disebabkan oleh pengedepanan tokoh perempuan sebagai individu. Namun, individu tersebut bukanlah identitas tunggal melainkan terhubung dengan yang Iain dan mengalami transformasi. Metafora sebagai penanda akhir dari patriaki tersebut berkait dengan benda-benda baik yang magis maupun yang nyata, seperti lingkaran, lingga, gong, dan peristiwa-peristiwanya.

Secara metaforis, lingkaran memiliki makna yang berkait dengan pola kosmis, kekuasaan spiritual raja, dan keseimbangan dalam gamelan Bali. Jika dihubungkan dengan lingga, lingkaran lingga berarti kekuasaan yang me nempatkan raja sebagai yang dipuja seperti dewa, juga dapat diartikan sebagai status atau posisi manusia dalam kehidupan yang berputar. Di samping lingkaran, gong mengaitkan puisi ini dengan seni pertunjukan yang mengangkat kisah mitos dan peran penabuh serta gamelan sebagai pengiring pertunjukan di dunia riil. Penanda lingkaran dan gong dalam puisi dapat dianggap sebagai simbol-simbol patriaki (kekuasaan laki-laki) yang berkait dengan mitos dan perempuan, tetapi keterkaitan penanda tersebut dengan tokoh dan peristiwa magis irreducible dapat dimaknai pula bahwa patriaki tersebut mengalami akhir atau didekonstruksi.

Akhir patriaki dalam puisi "Gong" berupa kesadaran terhadap perempuan yang dimarjinalkan dalam mitos dan pengakuan atas keterbatasan diri atau subjek, dan aku hanya lingkaran lingga. Terlalu purba, terlalu sederhana. Tak mampu aku memuasi dahagamu. Dahaga milik adinda berupa keinginan untuk terus menari yang menerabas batas ruang dan waktu, yang dapat dimaknai pula sebagai eksistensi mitos itu sendiri, sedangkan para penabuh dengan kematian sang panakawan menyebabkan adinda (perempuan) disalahpahami sebagai objek semata, maafkan kami, sebab kami penabuh yang takpernah mengaku. Peristiwa tarian adinda merupakan pengakuan terhadap perempuan (mitos) sebagai yang magis dan irasional, tetapi hal tersebut tidak dipandang rendah. Jika perempuan dalam mitos adalah objek patriaki sebagaimana seni pertunjukkan 
dalam realitas memperlakukannya, maka perempuan dalam puisi "Gong" adalah objek sekaligus subjek yang disadari oleh patriaki dalam batas-batas diri. Diri dalam puisi “Gong" adalah narator sebagai aku yang memandang perempuan sebagai yang magis, irasional, sekaligus juga yang nyata dan rasional, seperti parasku yang tak kunjung hancur, sehingga keduanya berada dalam hubungan kesetaraan, bukan subordinasi. Pendefinisian adinda, Ratna Manggali (perempuan), tidak sematamata ditentukan oleh kekuasaan laki-laki sebagai kebenaran mutlak, tetapi juga oleh pengakuan keterbatasan diri bahwa ada kebenaran 'yang lain'.

\section{Posmodernisme di Jakarta}

Sebagai karyarealismemagis, puisi “Gong" merupakan produk masyarakat postmodern. Sebagaimana diungkap oleh Piliang (2003: 62), sejak tiga dasawarsa terakhir terjadi peralihan dari masyarakat industri menuju masyarakat posindustri dan dari kebudayaan modern menuju posmodern yang mempengaruhi kesalingberkaitan antara manusia dan kebudayaan, serta antara manusia dan dunia objek-objek. Perubahan tersebut memunculkan masyarakat posmodern yang ditandai oleh beberapa ciri, di antaranya penggunaan teknologi informasi, globalisasi, dan konsumerisme. Di Indonesia, perubahan menuju masyarakat informasi yang merupakan bagian yang tak terpisahkan dari perubahan di tingkat global mulai terjadi pada 1950-an (Pujiharto, 2010: 102). Nirwan Dewanto tidak dapat dilepaskan dari perubahan kondisi itu sebagai konteks sosial nya di samping juga, aktivitas sastra, kesenian, dan pandangan serta pemikirannya mengenai hal itu.

Tidak dapat dimungkiri bahwa posmodernisme sebagai kritik atas modernisme baik pada tataran wacana maupun praktis di Jakarta muncul dalam berbagai bidang. Puisi "Gong" yang tercakup dalam Jantung Lebah R atu (2008) merupakan karya Nirwan Dewanto sebagai penyair yang tinggal di Jakarta. Oleh karena itu, keberadaan kelompok, arena, atau komunitas tempat ia terlibat dalam kegiatan sastra dan seni, khususnya pada komunitas yang berpengaruh ataupun dipengaruhinya sebagai tempat yang secara intensif ia berada di dalamnya, dapat menunjukkan kecenderungan perwujudan estetik. Saat ini, Nirwan Dewanto merupakan salah satu anggota dewan kurator di Komunitas Salihara. Sebagai komunitas seni yang representatif dan memiliki atmosfer kosmopolitan, melalui visi dan program keseniannya, Salihara dapat menandai posmodernitas di Jakarta.

Kondisi Jakarta yang posmodern menyebabkan hal-hal yang semula marjinal berubah posisinya menjadi pusat baru sebaliknya yang dianggap sebagai pusat dengan mudah ditinggalkan atau mengalami desentralisasi. $\mathrm{Hal}$ tersebut berlaku pula bagi sastra di Jakarta. Tema-tema yang berkait dengan mitos, tradisi, dan identitas tidak hanya dapat dipandang secara modernisme, tetapi juga secara posmodernisme. Situasi yang demikian memungkinkan realisme magis, sebagai sastra yang bersifat multikultur dan posmodern, memberikan pengaruh bagi karya sastra yang muncul di Jakarta.

Dalam sastra modern, mitos atau tradisi dapat diperlakukan sebagai alat untuk mengungkapkan gagasan modern atau dipahami sebagai entitas yang terpisah dari modernitas. Akan tetapi, dalam sastra posmodern segala yang diketepikan, termasuk mitos dan tradisi dipandang sebagai entitas yang tidak terpisah dari modernitas. Yang diceritakan justru persentuhannya, adaptasinya, dan juga strategi yang digunakan untuk menghadapi modernitas (Faruk, 2001: 24"26). Dalam sastra Indonesia, himpunan puisi J antung Lebah Ratu (2008) dapat dimasukkan ke dalam sastra posmodern dan secara khusus pada puisi "Gong" memperlihatkan adanya pengaruh realisme magis. Pengaruh itu diperlihatkan melalui sifat multikultur dan narasi realisme sekaligus magis terhadap mitos Calon Arang. 
Sifat multikultur puisi "Gong" diperlihatkan melalui identitas tokoh yang tidak tunggal dan saling terhubung satu sama lain. Sifat multikultur tersebut dengan demikian merupakan wacana atas identitas yang plural dan wacana atas tradisi (mitos) sebagaimana yang menjadi pandangan penyairnya. Dalam konteks Jakarta, Nirwan Dewanto (1996:78) menyatakan bahwa tradisi adalah pantulan langsung hidup itu sendiri. A neka tradisi menjejakkan kaki, berebut tempat di kedalaman bawah sadar. Betapa perlunya mengakui bahwa terutama di Jakarta, tak lagi dapat hidup dengan sebuah identitas murni, dengan sebuah kesatuan harmonis. Menerima keterpecahan dan disharmoni merupakan sebuah pendahuluan untuk sebuah 'strategi kebudayaan'.

Narasi realisme magis dapat seperti yang tergambar dalam puisi "Gong" karya Nirwan Dewanto disebabkan oleh cara pandang posmodernismeterhadap mitos. Puisi ini tidak me mandang mitos sebagaimana masyarakat tradisional dan modern memandangnya. Di daerah-daerah tradisional yang hidup dengan kepercayaan takhayul dan magis, mitos hidup dan diyakini secara kuat, yang menunjukkan lemahnya pengaruh modernitas. Akan tetapi, di daerah-daerah dengan tingkat modernitas tinggi , mitos dianggap sebagai entitas yang terpisah dari modernitas atau digunakan sebagai alat yang dimanfaatkan untuk kepentingan lain. Sebagai karya realisme magis, puisi ini memandang mitos sebagai yang magis, tradisional dalam hubungannya dengan yang riil, modern untuk menggarisbawahi isu mengenai identitas dalam konteks posmodern.

\section{PENUTUP}

\section{Simpulan}

Puisi “Gong" karya Nirwan Dewanto me rupakan puisi yang memperlihatkan pengaruh aliran sastra global berupa realisme magis. Terdapat lima karakteristik realisme magis, yaitu elemen taktereduksi, dunia fenomenal, keraguan takberakhir, penggabungan alam, dan gangguan terhadap waktu, ruang, dan identitas, yang ditemukan dalam puisi ini. Dari kelima karakteristik tersebut, tampak hubungan relasional di antara yang magis, tradisional dan yang nyata, dan modern. Selanjutnya, meIalui relasi antarelemen, dapat diperlihatkan susunan tingkat atau kadar antara unsur magis dan riil. Karya realisme magis melihat hubungan antara yang magis dan yang riil tidak secara hierarkis sebagaimana real isme, tetapi meletakkan posisi keduanya untuk disejajarkan. Berdasarkan kecenderungan tokoh-tokoh, benda, dan peristiwa-peristiwanya, puisi ini dapat dikatakan sebagai karya yang berada di antara realisme dan magis.

Puisi "Gong" melalui penarasian elemen taktereduksi juga simbol-simbol di dalamnya menggarisbawahi isu perempuan dan akhir patriaki yang menjadi alternatif bagi pemaknaan mitos Calon Arang, di samping juga isu mengenai identitas. Isu-isu tersebut terhubung dengan pandangan atas perempuan dalam konteks posmodernisme dan konteks sosial tempat penyair berada. Puisi ini memosisikan Ratna Manggali bukan sebagai korban. Selain itu, mitos dalam puisi berkait dengan benda dan tokoh nyata dalam dunia fenomenal. Puisi ini menampilkan hubungan antara tokoh perempuan dan yang lain, dalam kaitannya dengan kekuatan ataupun kekuasaan, melalui metafora, juga simbol yang menunjukkan akhir dari patriaki.

Pendeskripsian tokoh mitos Ratna Manggali secara mendetail, konkret, sekaligus misterius. dan memiliki kekuatan magis merupakan sisi modernisme, tetapi pertanyaan yang ditimbulkan atas keberadaan tokoh melalui peristiwa tariannya dan pertentangan antara alamalam (dunia) yang berbeda merupakan sisi posmodernisme karya. Ratna Manggali (adinda) terhubung dengan identitas tokoh-tokoh lain, baik dalam posisi magis maupun nyata. Penggunaan mitos dalam puisi ini dengan demikian 
memperlihatkan cara pandang posmodernisme terhadap mitos.

\section{DAFTAR PUSTAKA}

Bandem, I Made. 1996. Etnologi Tari Bari. Yogyakarta: Kanisius dan Forum A presiasi Kebudayan, Denpasar, Bali.

Banoe, Pono. 2003. Kamus M usik. Yogyakarta: Kanisius.

Bianpoen, Carla. 2006. “The King's Witch' Weaves a New Version of an Old Story". Jakarta Post. 01 Desember 2006.

Bowers, Maggie Ann. 2004. M agic(al) Realism. London and New York: Routledge.

Dewanto, Nirwan. 1996. Senjakala Kebudayaan. Yogyakarta: Bentang.

——_. 1999. "M engolah Pinggiran: Jorge Luis Borges dan Khazanah Amerika Selatan". Pengantar Labirin Impian. Karya Jorge Luis Borges. Yogyakarta: LKIS.

_- . 2008. Jantung Lebah Ratu. Jakarta: Gramedia.

Faris, Wendy B. 2004. Ordinary Enchantments: $M$ agical Realism and the Remystification of N arrative. Nashville: Vanderbilt University Press.

Faruk, H.T. 2001. Beyond Imagination: Sastra M utakhir dan Ideologi. Yogyakarta: Gama Media.

Geertz, Clifford. 1980. N egara: the Theather State in $\mathrm{N}$ ineteenth-Century Bali. New Jersey: Princeton University Pres.

Hart, Stephen M. dan Wen-Chin Ouyang. 2005. A Companion to Magical Realism. Woodbridge: Tamesis.

Iswandari, Retno. 2014. Realisme M agis dalam Puisi "Gendhing Pulebahasan" Karya Badruddin Emce: Konsep Karakteristik Realisme $\mathrm{M}$ agis $\mathrm{W}$ endy $\mathrm{B}$ Faris. Tesis. Tidak Diterbitkan. Pascasarjana Fakultas IImu Budaya, UGM, Yogyakarta.

Luxemburg, Jan Val, dkk. 1989. Pengantar IImu Sastra. Terjemahan Dick Hartoko. Jakarta: Gramedia.
Heraty, Toeti. 2000. Calon A rang: Kisah Perempuan Korban Patriaki. Jakarta: Gramedia.

McHale, Brian. 2009. Beginning To Think A bout $\mathrm{N}$ arrative in Poetry. www.muse.jhu.edu

Mohamad, Gunawan. 2000. “The King's Witch". M anoa, Vol. 12, No. 1, 2000, http:/ / muse.jhu.edu/ journals/ man/ summary/ v012/ 12.1mohamad.html.

Mu'jizah. 1995. Calon A rang dari Jirah. Jakarta: Pusat Pembinaan dan Pengembangan Bahasa, Depdikbud.

Piliang, Yasraf A mir. 2003. H ipersemiotika: Tafsir Cultural Studies atas M atinya M akna. Yogyakarta: Jalasutra.

Sawitri, Cok. 2007. Janda dari Jirah. Cet. ke-1. Jakarta: Gramedia Pustaka Utama.

Soedarsono, R.M dan Tati Narawati. 2011. Dramatari di Indonesia, Kontinuitas dan Perubahan. Yogyakarta: Gadjah Mada University Press.

Soelarso, B dan S. Ilmi Albiladiyah. 1975. Pertunjukan Rakyat Drama Gong dari Bali. Jakarta: Proyek Pengembangan Media Kebudayaan, Ditjen Kebudayaan, Depdikbud.

Spiller, Henry. 2004. Gamelan: Traditional Sounds of Indonesia. California: ABC CLIO.

Takwin, Bagus. 2009. “Jantung Lebah Ratu: Ikhtiar Melampaui Rezim Indrawi, Menghadirkan yang Takterungkap Bahasa". Jakarta: Arsip Salihara.

Toer, Pramoedya A nanta. 2003. Cerita Calon A rang. Cet. ke-5. Jakarta: Lentera Dipantara.

Yuliadi, Koes. 2005. Drama Gong di Bali. Cet. ke-1. Yogyakarta: PB ISI.

Zoetmulder. 1994. Kalangwan: Sastra Jawa Kuno Selayang Pandang. Cet. ke-3. Jakarta: Penerbit Djambatan. 